\title{
Energy and exergy efficiency of water-based photovoltaic thermal (PVT) systems: an overview
}

\author{
Nurul Shahirah Binti Rukman', Ahmad Fudholi², Ivan Taslim ${ }^{3}$, Merita Ayu Indrianti ${ }^{4}$, \\ Intan Noviantari Manyoe ${ }^{5}$, Uce Lestari ${ }^{6}$, Kamaruzzaman Sopian ${ }^{7}$ \\ 1,2,7 Solar Energy Research Institute, Universiti Kebangsaan Malaysia, 43600 Bangi Selangor, Malaysia \\ ${ }^{3,4}$ Universitas Muhammadiyah Gorontalo, Indonesia \\ ${ }^{5}$ Universitas Negeri Gorontalo, Indonesia \\ ${ }^{6}$ Pharmaceutical Study Program, Faculty of Science and Technology, University of Jambi, Indonesia
}

\begin{tabular}{l}
\hline Article Info \\
\hline Article history: \\
Received Aug 15, 2018 \\
Revised Nov 19, 2018 \\
Accepted Jan 28, 2019 \\
\hline Keywords: \\
Energy analysis \\
Exergy analysis \\
Photovoltaic \\
Renewable energy \\
Solar energy \\
\hline
\end{tabular}

\begin{abstract}
Conventional fuels are not free, scarce and expensive, and its future cost and availability are uncertain. Hence, the usage of solar energy in applications will probably increase and further become economically feasible in the near future. Solar energy is free, clean, and renewable and has been widely used in electricity generation and thermal energy via photovoltaic thermal (PVT) system. PVT is a hybrid system consists of a PV panel and a solar collector in a single unit to simultaneously produce electricity and thermal energy. In this review, energy and exergy efficiency for water-based PVT systems is presented. As conclusion, the study on exergy is still limited and is recommended to be furthered in order to obtained useful energy generation by the system.
\end{abstract}

Copyright (c) 2019 Institute of Advanced Engineering and Science. All rights reserved.

\section{Corresponding Author:}

Ivan Taslim,

Universitas Muhammadiyah Gorontalo, Indonesia.

Email: ivantaslim@umgo.ac.id

\section{INTRODUCTION}

These past days has governed the adancements of technologies by sourcing solar energy as the energy input. Due to the sustainability of solar source, the renewability of the energy had contributed to the employment of them in most of recent applications. The most promising technology that made great pace in advancement is photovoltaic (PV) technology which using solar panel in converting sunlight to electrical energy. As further studies has been continued, photovoltaic thermal (PVT) system has been introduced which is the combi system of PV and heat collector system. The PV panel absorbs the solar radiation while the heat collector system acts as to remove heat from the PV to regulate the temperature of panel, avoiding extreme hot condition of panel during the operation. Thus, PVT system produces both electrical and thermal energies from one integrated system; drawing high attention from lots of studies regarding its prospects in fullfilling the energy demand. PVT system is a promising system to generate both energies due to its high reliability system with low environment impact. Primarily, the focus of study was on glazed collectors or panel; both air-based and water-based system.

The differences were the coolants used either air or water in the heat collector or cooling system. Among the application of these systems as had been used for building integrated photovoltaic thermal (BIPVT) system. Generally, a water-based PVT system system comprising with PV module, absorber collector in the designated tubes, the glass cover, and insulated container. An air-based PVT system consists of a PV panel and a thermal collector system. The system can produce electrical energy directly converted from solar radiation, while extracting heat from the PV panel and warm the air flow inside the collector; as 
well as for utilizing water in water-based PVT system. These explain the production of hot air and hot water from the water-based and air-based PVT systems [1-15].

In the mid-1970s, a study with the focus on PVT systems, aiming to increase the PV efficiency had been carried out. In the meantime, to meet the deployment of the technology in domestic application was regarded as the main market [16]. In this review, energy and exergy efficiency of water-based PVT systems is presented, and types of water-based PVT system is described.

\section{TYPES OF WATER-BASED PVT SYSTEMS}

Utilization of water as coolants in PVT systems which also known as water-based PVT systems had been experienced great advancements. Based on the researches that had been conducted as shown in Figure 1, flow pattern of coolant in water-based PVT systems can be categorised into theree types are: (i) natural flow, (ii) force flow and (iii) hybrid system.

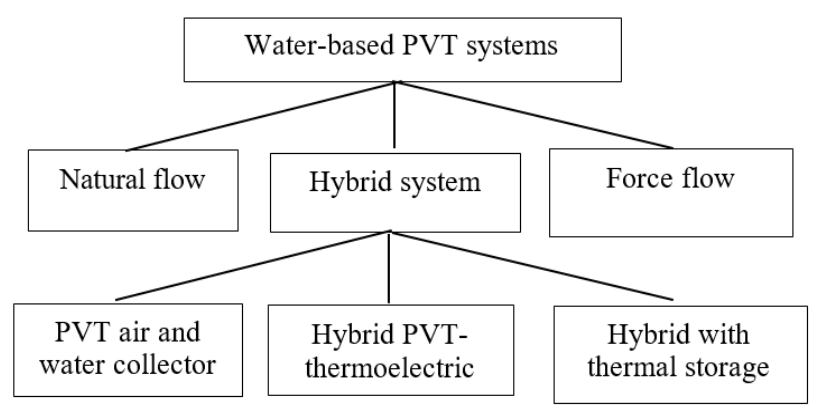

Figure 1. Classifications of flow pattern in water-based PVT systems

\section{STUDIES CONDUCTED ON WATER-BASED PVT SYSTEMS}

Afterwards, an evaluation of combined PVT systems also had been carried out by Hendrie [17] which the performances of both electrical and thermal energy had been evaluated by yielding sharp relation to the theoretical results. From the research, it had proved that PVT collector system can assured in having potential for useful and greater thermal and electrical energy gain. From his theoretical studies, he also concluded that the analytical models can be used in predicting the energy production's performances as it gave an accurate data.

An experimental study also had been conducted by Erdil et al. [18] which focused on energy generation with a PV- solar thermal hybrid system by using water as coolants. Two experimental modules had been used as the hybrid system while input/output diverse system had been installed in order to ensure constant flow circulation of water across the cavity.

First, the investigation on water-based PVT systems under continuous assortment of temperature mode with unlike constant flow rate mode by Mishra and Tiwari [19] had been compared for two panel's configuration which partially covered and fully covered PV module. The partially covered PV had been shown that the case was preferable for hot water or high thermal yield production meanwhile the one with fully covered resulted in generating higher electrical gain, hence better for primary requirement of obtaining high electrical gain.

Chow et al. [20] also had studied dissimilar water-based PVT system which resulting that unglazed PVT generated higher thermal energy than glazed PVT. Other than that, Shyam et al. [21] had concluded from a study on partially covered PV module of water-based PVT system connected in series, that the temperature reliant on module efficiency, tank and outlet water temperature have been validated for the water-based PVT system.

Other than that, exergy efficiency was investigated experimentally and mathematically which more realistic and practical view of process than energy analysis method [22]. Agrawal and Garg [23] also have studied the energy performance a water-based PVT system. Difference method had been used to simulate the performance of the water-based PVT system. Their results indicated that water-based PVT systems generated satisfactory electrical energy for domestic usages.

Int J Pow Elec \& Dri Syst, Vol. 10, No. 2, June 2019 : 987 - 994 


\section{ENERGY AND EXERGY EFFICIENCY OF WATER-BASED PVT SYSTEMS}

Exergy theory also had been used in term of attaining analysis on performance of water-based PVT system, experimentally. From their annual experimental assessment, they determined that the water-based PVT system can produce better exergy output than a unit of PV module or water collector [24]. Tiwari and Sodha [25] also had established a thermal model for a water-based PVT system and conveyed that a daily thermal efficiency of around 58\% had been achieved. Dubey and Tiwari [26] have designed and verified an unsteady state system of water-based PVT system. An observation of it performed better thermal and average cell efficiency which is in accordance with previous research. Then, Tiwari et al. [27] had come to conclude that the overall exergy and thermal efficiency of PVT system is maximum at mass flow rate of $0.006 \mathrm{~kg} / \mathrm{s}$.

In 2014, a thermal model had been designed to test for electrical efficiency of a-Si PV module. Water flow had been implied on the front of panel in open loop condition for cooling the PV module. Water flow over the PV module had been concluded as improving its efficiency as this design was where the drained water, had been unused and also without integrating it with any plate water collector assembly [28]. Then, in the same year, it had been approved by Herrando et al. [29] that water is the best heat removal compared to air. A presentation of a numerical model had been studied by Boubekri et al. [30] to testify the electrical performance of a collecting hybrid water-based PVT system which it had been shown that the overall efficiency of the collector also can be influenced by the inclination angle, the mass flow rate of water and the conduction heat transfer coefficient in the adhesive layer.

Kalogirou et al. [31] also led a simulation on the industry of PVT systems with water heat extraction in three places with different latitudes, and also using different type of solar cells. The previous study had approved on the water efficiency as heat extraction and as well as latitudes that influences the energy generation. Meanwhile, as for this study which used different solar cells, it had been emerged that the electricity generation is higher for polycrystalline solar cells whereby amorphous solar cells produced slightly higher thermal contributions. Beforehand in 2006, a computer simulation was performed which concentrating on the combined effects of solar cell packing factor and water mass flow rate. These factors were the variables to study on the electrical and thermal efficiencies. It had reconfirmed that system operation at the optimum mass flow rate improved the thermal performance. However, it then lessening when a critical mass flow is surpassed [32]. Energy and exergy analysis of water-based PVT systems by different researchers as shown in Table 1.

Table 1. Performances of water-based PVT systems

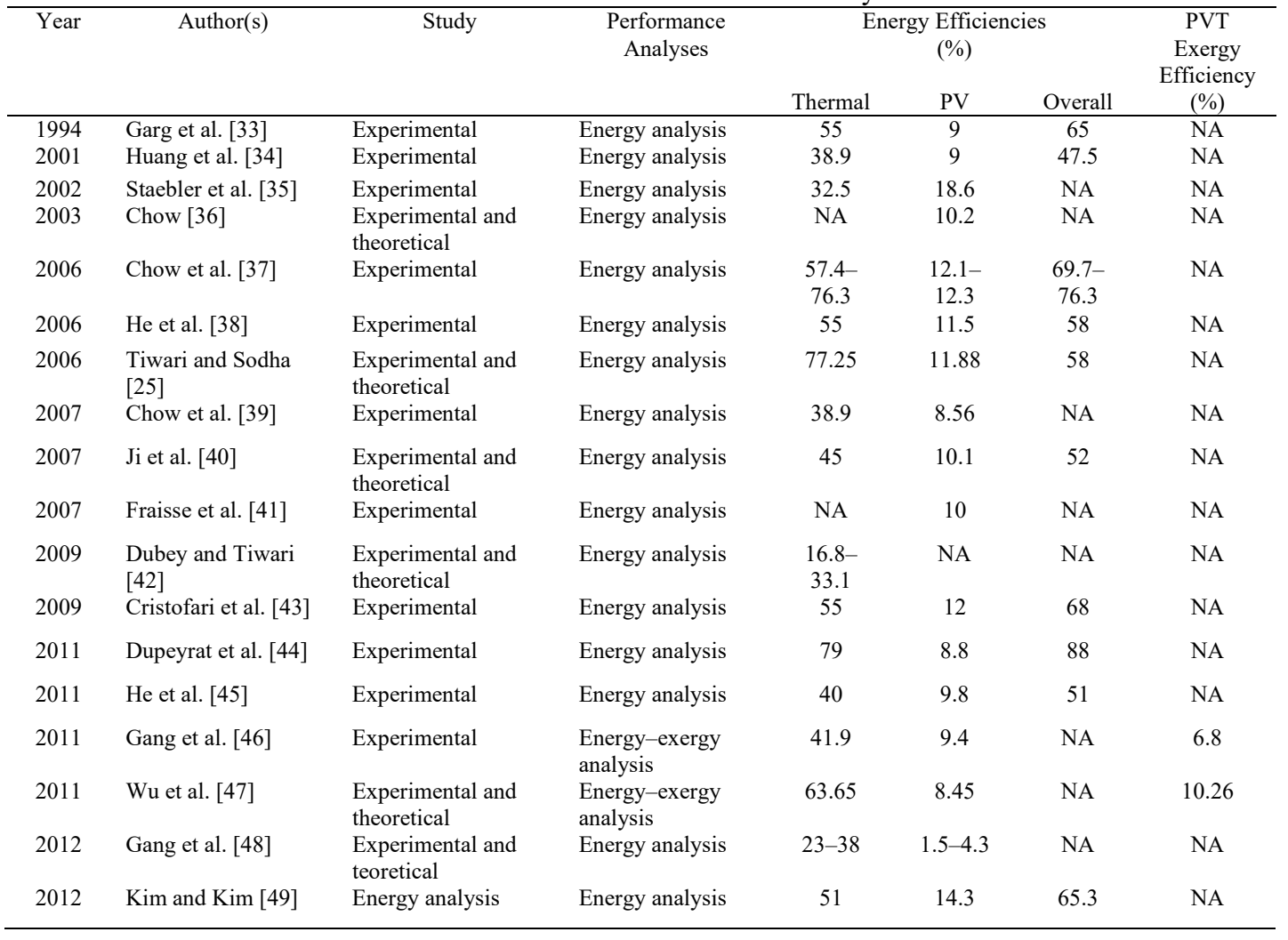


Table 1. Performances of water-based PVT systems

\begin{tabular}{|c|c|c|c|c|c|c|c|}
\hline \multirow[t]{2}{*}{ Year } & \multirow[t]{2}{*}{ Author(s) } & \multirow[t]{2}{*}{ Study } & \multirow[t]{2}{*}{$\begin{array}{l}\text { Performance } \\
\text { Analyses }\end{array}$} & \multicolumn{3}{|c|}{$\begin{array}{c}\text { Energy Efficiencies } \\
(\%)\end{array}$} & \multirow{2}{*}{$\begin{array}{c}\text { PVT } \\
\text { Exergy } \\
\text { Efficiency } \\
(\%) \\
\end{array}$} \\
\hline & & & & Thermal & PV & Overall & \\
\hline & (Cont.) & & & & & & \\
\hline 2012 & Kim and Kim [50] & Experimental & Energy analysis & $66-70$ & $14-15$ & $70-85$ & NA \\
\hline 2012 & Cristofari et al. [51] & Experimental & Energy analysis & 29 & 14 & 43 & NA \\
\hline 2013 & Dubey and Tay [52] & Experimental & Energy analysis & $\begin{array}{c}39.4- \\
40.7\end{array}$ & $\begin{array}{c}11.4- \\
11.8\end{array}$ & NA & NA \\
\hline 2013 & $\begin{array}{l}\text { Mishra and Tiwari } \\
\text { [19] }\end{array}$ & Experimental & $\begin{array}{l}\text { Energy-exergy } \\
\text { analysis }\end{array}$ & $\begin{array}{c}28.2- \\
45.9\end{array}$ & $\begin{array}{c}10.0- \\
10.4\end{array}$ & NA & NA \\
\hline 2013 & $\begin{array}{l}\text { Axaopoulos and } \\
\text { Fylladitakis [53] }\end{array}$ & Theoretical & $\begin{array}{l}\text { Energy-economic } \\
\text { analysis }\end{array}$ & 17.7 & NA & NA & NA \\
\hline 2014 & Ibrahim et al. [54] & Experimental & $\begin{array}{l}\text { Energy-exergy } \\
\text { analysis }\end{array}$ & $55-62$ & 11.4 & NA & $12.0-14$ \\
\hline 2014 & Fudholi et al. [55] & Experimental & Energy analysis & 54.6 & 13.8 & 68.4 & NA \\
\hline 2015 & Aste et al. [46] & $\begin{array}{l}\text { Experimental and } \\
\text { theoretical }\end{array}$ & Energy analysis & 28.8 & 13.2 & 42 & NA \\
\hline 2015 & Good et al. [57] & Experimental & Energy analysis & 71.5 & 17.4 & NA & NA \\
\hline 2015 & Shyam et al. [58] & Theoretical & Energy analysis & $44.6-49$ & $\begin{array}{c}10.2- \\
10.8\end{array}$ & NA & NA \\
\hline 2015 & Tiwari et al. [59] & $\begin{array}{l}\text { Experimental and } \\
\text { theoretical }\end{array}$ & $\begin{array}{l}\text { Energy-exergo- } \\
\text { economic-enviro- } \\
\text { economic analysis }\end{array}$ & NA & $\begin{array}{l}13.4 \\
23.2\end{array}$ & $\begin{array}{c}28.5- \\
53.4\end{array}$ & NA \\
\hline 2016 & Aste et al. [60] & $\begin{array}{l}\text { Experimental and } \\
\text { theoretical }\end{array}$ & Energy analysis & $20.8-45$ & $\begin{array}{c}13.4- \\
13.7\end{array}$ & $\begin{array}{c}32.7- \\
40.6\end{array}$ & NA \\
\hline 2016 & Rosa-Clot et al. [61] & Experimental & Energy analysis & 62 & 13.19 & NA & NA \\
\hline 2016 & Tse et al. [62] & Theoretical & $\begin{array}{l}\text { Energy-economic } \\
\text { analysis }\end{array}$ & NA & 16 & NA & NA \\
\hline 2016 & $\begin{array}{l}\text { Yazdanifard et al. } \\
\text { [63] }\end{array}$ & Theoretical & $\begin{array}{l}\text { Energy-exergy } \\
\text { analysis }\end{array}$ & 70 & 17 & NA & NA \\
\hline 2016 & Singh et al. [64] & $\begin{array}{l}\text { Experimental and } \\
\text { theoretical }\end{array}$ & $\begin{array}{l}\text { Energy-exergy } \\
\text { analysis }\end{array}$ & 69.06 & NA & 75 & NA \\
\hline 2016 & Tripathi et al. [65] & $\begin{array}{l}\text { Experimental and } \\
\text { theoretical }\end{array}$ & $\begin{array}{l}\text { Energy-exergy- } \\
\text { enviro-economic } \\
\text { analysis }\end{array}$ & $40-50$ & NA & $45-63$ & NA \\
\hline 2016 & Xu et al. [66] & $\begin{array}{l}\text { Experimental and } \\
\text { theoretical }\end{array}$ & Energy analysis & 60 & 28 & NA & NA \\
\hline 2017 & Aste et al. [67] & Experimental & Energy analysis & 29.4 & $6.0-14.2$ & $\begin{array}{c}42.3- \\
52.6\end{array}$ & NA \\
\hline 2017 & Hui et al. [68] & $\begin{array}{l}\text { Experimental and } \\
\text { theoretical }\end{array}$ & Energy analysis & 35 & 10 & NA & NA \\
\hline 2017 & Modjinou et al. [69] & $\begin{array}{l}\text { Experimental and } \\
\text { theoretical }\end{array}$ & Energy analysis & 54 & 7.6 & NA & NA \\
\hline 2017 & Liang et al. [70] & $\begin{array}{l}\text { Experimental and } \\
\text { theoretical }\end{array}$ & Energy analysis & $45-62$ & $\begin{array}{c}14.25- \\
15.92\end{array}$ & NA & NA \\
\hline 2017 & Lari and Sahin [71] & $\begin{array}{l}\text { Experimental and } \\
\text { theoretical }\end{array}$ & $\begin{array}{l}\text { Energy-exergy- } \\
\text { economic analysis }\end{array}$ & NA & 13.2 & NA & NA \\
\hline 2017 & Salem et al. [72] & Experimental & $\begin{array}{l}\text { Energy-exergy } \\
\text { analysis }\end{array}$ & $\begin{array}{c}31.6- \\
57.9\end{array}$ & $\begin{array}{c}17.7- \\
38.4\end{array}$ & $59.3-92$ & $11.1-13.5$ \\
\hline
\end{tabular}

\section{CONCLUSION}

In this review, water-based PVT systems had been summarized which comprising the studies that had been carried out previously on the advancement of this system. Production of hot water, portrayed by the thermal gain more than $50 \%$. Though, the study on exergy is still limited and is recommended to be furthered in order to obtained useful energy generation by the system.

\section{ACKNOWLEDGEMENTS}

The authors gratefully acknowledge the funding from the USAID through SHERA program-Centre for Development of Sustainable Region (CDSR). The authors would like to thanks the UKM for support. 


\section{REFERENCES}

[1] N.S. Nazri, et al., "Energy economic analysis of photovoltaic-thermal-thermoelectric (PVT-TE) air collectors". Renewable and Sustainable Energy Review, vol. 92, pp. 187-97, 2018.

[2] N.S. Nazri, et al., "Mathematical modeling of photovoltaic thermal-thermoelectric (PVT-TE) air collector". International Journal of Power Electronics and Drive Systems (IJPEDS), vol. 9, no. 2, pp. 795-802, 2018

[3] M. Zohri, et al., "Photovoltaic thermal (PVT) system with and without fins collector: theoretical approach". International Journal of Power Electronics and Drive System (IJPEDS), vol. 8, no. 4, pp. 1756-63, 2017.

[4] A. Fudholi, et al., "Review on exergy and energy analysis of solar air heater. International Journal of Power Electronics and Drive Systems (IJPEDS), vol. 9, no. 1, pp. 420-26, 2018.

[5] A. Fudholi, et al., "Review on solar collector for agricultural produce". International Journal of Power Electronics and Drive Systems (IJPEDS), vol. 9, no. 1, pp. 414-19, 2018.

[6] A. Fudholi, et al., "R\&D of photovoltaic thermal (PVT) systems: an overview“. International Journal of Power Electronics and Drive Systems (IJPEDS), vol. 9(2), pp. 803-10, 2018.

[7] A. Fudholi, et al., "Primary study of tracking photovoltaic system for mobile station in Malaysia“. International Journal of Power Electronics and Drive Systems (IJPEDS), vol. 9(1), pp. 427-32, 2018.

[8] A. Fudholi, et al., "Design and testing of solar dryer for drying kinetics of seaweed in Malaysia," in Proc. of the 5th Int. Conf. on Energy and Development- Environment - Biomedicine (EDEP'11), Corfu, 2011, pp. 119-124.

[9] C.N. Aisyah et al., "Kecekapan pengumpul PV/T menggunakan pengumpul terma reka bentuk pilin (Efficiency of $\mathrm{PV} / \mathrm{T}$ collector using spiral thermal absorber design), Sains Malaysiana, vol. 47, no. 4, pp. 853-859, 2018.

[10] A. Fudholi, et al., "Energy and exergy analyses of photovoltaic thermal collector with $\nabla$-groove," Solar Energy, vol. 159, pp. 742-50, 2018.

[11] A. Fudholi, et al., "Performance analysis of photovoltaic thermal (PVT) water collectors,"Energy Conversion and Management, vol. 78, pp. 641-651, 2014.

[12] M. Zohri, et al., "Exergy assessment of photovoltaic thermal with v-groove collector using theoretical study. TELKOMNIKA, vol. 16(2), pp. 550-57, 2018.

[13] A. Ibrahim et al., "Efficiencies and improvement potential of building integrated photovoltaic thermal (BIPVT) system," Energy Conversion and Management, vol. 77, pp. 527-34, 2014.

[14] M.Y. Othman, et al., "Performance analysis of a double-pass photovoltaic/thermal (PV/T) solar collector with CPC and fins". Renewable energy, vol. 30, pp. 2005-2017, 2005.

[15] M.Y. Othman, et al., "Performance studies on a finned double-pass photovoltaic-thermal (PV/T) solar collector". Desalination, vol. 209(1-3), pp. 43-49, 2007.

[16] M. Wolf, "Performance analyses of combined heating and photovoltaic power systems for residences," Energy Conversion, vol. 16, no. 1-2, pp. 79-90, Jan. 1976.

[17] Hendrie and S.D., "Evaluation of combined photovoltaic/thermal collectors." 01-Jan-1979.

[18] E. Erdil, M. Ilkan, and F. Egelioglu, "An experimental study on energy generation with a photovoltaic (PV)-solar thermal hybrid system," Energy, vol. 33, no. 8, pp. 1241-1245, Aug. 2008.

[19] R. K. Mishra and G. N. Tiwari, "Energy and exergy analysis of hybrid photovoltaic thermal water collector for constant collection temperature mode," Solar Energy, vol. 90, pp. 58-67, Apr. 2013.

[20] T. T. Chow, G. Pei, K. F. Fong, Z. Lin, A. L. S. Chan, and J. Ji, "Energy and exergy analysis of photovoltaicthermal collector with and without glass cover," Applied Energy, vol. 86, no. 3, pp. 310-316, Mar. 2009.

[21] Shyam, G. N. Tiwari, O. Fischer, R. K. Mishra, and I. M. Al-Helal, "Performance evaluation of N-photovoltaic thermal (PVT) water collectors partially covered by photovoltaic module connected in series: An experimental study," Solar Energy, vol. 134, pp. 302-313, Sep. 2016.

[22] J. Yazdanpanahi, F. Sarhaddi, and M. Mahdavi Adeli, "Experimental investigation of exergy efficiency of a solar photovoltaic thermal (PVT) water collector based on exergy losses," Solar Energy, vol. 118, pp. 197-208, Aug. 2015.

[23] R. K. Agarwal and H. P. Garg, "Study of a photovoltaic-thermal system-thermosyphonic solar water heater combined with solar cells," 1994.

[24] T. Fujisawa and T. Tani, "Annual exergy evaluation on photovoltaic-thermal hybrid collector," Solar Energy Materials and Solar Cells, vol. 47, no. 1-4, pp. 135-148, 1997.

[25] A. Tiwari and M. S. Sodha, "Performance evaluation of solar PV/T system: An experimental validation," Solar Energy, vol. 80, no. 7, pp. 751-759, 2006.

[26] S. Dubey and G. N. Tiwari, "Thermal modeling of a combined system of photovoltaic thermal (PV/T) solar water heater," Solar Energy, vol. 82, no. 7, pp. 602-612, 2008.

[27] A. Tiwari et al, "Exergy analysis of integrated photovoltaic thermal solar water heater under constant flow rate and constant collection temperature modes," Applied Energy, vol. 86, no. 12, pp. 2592-2597, 2009.

[28] A. Gaur and G. N. Tiwari, "Performance of a-Si thin film PV modules with and without water flow: An experimental validation," Applied Energy, vol. 128, pp. 184-191, 2014.

[29] M. Herrando et al, "A UK-based assessment of hybrid PV and solar-thermal systems for domestic heating and power: System performance,” Applied Energy, vol. 122, pp. 288-309, 2014.

[30] M. Boubekri et al, "Numerical approach for performance study of hybrid PV/Thermal collector," Revue des Energies Renouvelables, vol. 12, pp. 355-368, 2009.

[31] S. A. Kalogirou and Y. Tripanagnostopoulos, "Industrial application of PV/T solar energy systems," Applied Thermal Engineering, vol. 27, no. 8-9, pp. 1259-1270, 2007.

[32] J. Ji et al., "Effect of fluid flow and packing factor on energy performance of a wall-mounted hybrid photovoltaic/water-heating collector system," Energy and Buildings, vol. 38, no. 12, pp. 1380-1387, 2006. 
[33] H. P. Garg, R. K. Agarwal, and J. C. Joshi, "Experimental study on a hybrid photovoltaic-thermal solar water heater and its performance predictions," Energy Conversion and Management, vol. 35, no. 7, pp. 621-633, Jul. 1994.

[34] B. . Huang et al, "Performance evaluation of solar photovoltaic/thermal systems," Solar Energy, vol. 70, no. 5, pp. 443-448, 2001.

[35] D. L. Staebler et al, "Development of high efficiency hybrid PV-thermal modules," in Conference Record of the Twenty-Ninth IEEE Photovoltaic Specialists Conference, pp. 1660-1663, 2002.

[36] T. T. Chow, "Performance analysis of photovoltaic-thermal collector by explicit dynamic model," Solar Energy, vol. 75 , no. 2, pp. 143-152, 2003.

[37] T. T. Chow et al, "Hybrid photovoltaic-thermosyphon water heating system for residential application," Solar Energy, vol. 80, no. 3, pp. 298-306, 2006.

[38] W. He et al, "Hybrid photovoltaic and thermal solar-collector designed for natural circulation of water," Applied Energy, vol. 83, no. 3, pp. 199-210, 2006.

[39] T. T. Chow et al, "An experimental study of façade-integrated photovoltaic/water-heating system," Applied Thermal Engineering, vol. 27, no. 1, pp. 37-45, 2007.

[40] J. Ji et al, "A sensitivity study of a hybrid photovoltaic/thermal water-heating system with natural circulation," Applied Energy, vol. 84, no. 2, pp. 222-237, 2007.

[41] G. Fraisse et al, "Energy performance of water hybrid PV/T collectors applied to combisystems of Direct Solar Floor type," Solar Energy, vol. 81, no. 11, pp. 1426-1438, 2007.

[42] S. Dubey and G. N. Tiwari, "Analysis of PV/T flat plate water collectors connected in series," Solar Energy, vol. 83, no. 9, pp. 1485-1498, 2009.

[43] C. Cristofari et al, "Thermal behavior of a copolymer PV/Th solar system in low flow rate conditions," Solar Energy, vol. 83, no. 8, pp. 1123-1138, 2009.

[44] P. Dupeyrat et al, "Efficient single glazed flat plate photovoltaic-thermal hybrid collector for domestic hot water system," Solar Energy, vol. 85, no. 7, pp. 1457-1468, 2011.

[45] W. He et al, "Comparative experiment study on photovoltaic and thermal solar system under natural circulation of water," Applied Thermal Engineering, vol. 31, no. 16, pp. 3369-3376, 2011.

[46] P. Gang et al, "A numerical and experimental study on a heat pipe PV/T system," Solar Energy, vol. 85, no. 5, pp. 911-921, 2011

[47] S.-Y. Wu et al, "A heat pipe photovoltaic/thermal (PV/T) hybrid system and its performance evaluation," Energy and Buildings, vol. 43, no. 12, pp. 3558-3567, 2011.

[48] P. Gang et al, "Annual analysis of heat pipe PV/T systems for domestic hot water and electricity production," Energy Conversion and Management, vol. 56, pp. 8-21, 2012.

[49] J.-H. Kim and J.-T. Kim, "The Experimental Performance of an Unglazed PV-thermal Collector with a Fully Wetted Absorber," Energy Procedia, vol. 30, pp. 144-151, 2012.

[50] J.-H. Kim and J.-T. Kim, "The Experimental Performance of an Unglazed PVT Collector with Two Different Absorber Types," International Journal of Photoenergy, vol. 2012, pp. 1-6, 2012.

[51] C. Cristofari et al, "Innovative patented PV/TH Solar Collector: optimization and performance evaluation," Energy Procedia, vol. 14, pp. 235-240, 2012.

[52] S. Dubey and A. A. O. Tay, "Testing of two different types of photovoltaic-thermal (PVT) modules with heat flow pattern under tropical climatic conditions," Energy for Sustainable Development, vol. 17, no. 1, pp. 1-12, 2013.

[53] P. J. Axaopoulos and E. D. Fylladitakis, "Performance and economic evaluation of a hybrid photovoltaic/thermal solar system for residential applications," Energy and Buildings, vol. 65, pp. 488-496, 2013.

[54] A. Ibrahim et al, "Efficiencies and improvement potential of building integrated photovoltaic thermal (BIPVT) system," Energy Conversion and Management, vol. 77, pp. 527-534, 2014.

[55] A. Fudholi et al, "Performance analysis of photovoltaic thermal (PVT) water collectors," Energy Conversion and Management, vol. 78, pp. 641-651, 2014.

[56] N. Aste et al, "Design, modeling and performance monitoring of a photovoltaic-thermal (PVT) water collector," Solar Energy, vol. 112, pp. 85-99, 2015.

[57] C. Good et al, "Solar energy for net zero energy buildings - A comparison between solar thermal, PV and photovoltaic-thermal (PV/T) systems," Solar Energy, vol. 122, pp. 986-996, 2015.

[58] Shyam et al, "Analytical expression of temperature dependent electrical efficiency of N-PVT water collectors connected in series," Solar Energy, vol. 114, pp. 61-76, 2015.

[59] G. N. Tiwari et al, "Exergoeconomic and enviroeconomic analyses of partially covered photovoltaic flat plate collector active solar distillation system," Desalination, vol. 367, pp. 186-196, 2015.

[60] N. Aste et al, "Performance monitoring and modeling of an uncovered photovoltaic-thermal (PVT) water collector," Solar Energy, vol. 135, pp. 551-568, 2016.

[61] M. Rosa-Clot et al, "Experimental photovoltaic-thermal Power Plants based on TESPI panel," Solar Energy, vol. 133, pp. 305-314, 2016.

[62] K.-K. Tse et al, "Performance evaluation and economic analysis of a full scale water-based photovoltaic/thermal (PV/T) system in an office building," Energy and Buildings, vol. 122, pp. 42-52, 2016.

[63] F. Yazdanifard et al, "Investigating the performance of a water-based photovoltaic/thermal (PV/T) collector in laminar and turbulent flow regime," Renewable Energy, vol. 99, pp. 295-306, 2016.

[64] D. B. Singh et al, "Experimental studies of active solar still integrated with two hybrid PVT collectors," Solar Energy, vol. 130, pp. 207-223, 2016.

Int J Pow Elec \& Dri Syst, Vol. 10, No. 2, June 2019 : 987 - 994 
[65] R. Tripathi et al, "Overall energy, exergy and carbon credit analysis of N partially covered Photovoltaic Thermal (PVT) concentrating collector connected in series," Solar Energy, vol. 136, pp. 260-267, 2016.

[66] N. Xu et al, "Numerical simulation and experimental validation of a high concentration photovoltaic/thermal module based on point-focus Fresnel lens," Applied Energy, vol. 168, pp. 269-281, 2016.

[67] C. Del et al., "Energy Analysis of Biosystem Structures: Case study on Poultry Farms View project SET4FoodSustainable Energy Technologies for Food security in humanitarian contexts View project Niccolò Aste Politecnico di Milano ScienceDirect Water PVT collectors perfor," 2017.

[68] H. Long et al, "Building-integrated heat pipe photovoltaic/thermal system for use in Hong Kong," Solar Energy, vol. 155, pp. 1084-1091, 2017.

[69] M. Modjinou et al, "A numerical and experimental study of micro-channel heat pipe solar photovoltaics thermal system," Applied Energy, vol. 206, pp. 708-722, 2017.

[70] R. Liang et al, "Performance evaluation of sheet-and-tube hybrid photovoltaic/thermal (PVT) collectors connected in series," Procedia Engineering, vol. 205, pp. 461-468, 2017.

[71] M. O. Lari and A. Z. Sahin, "Design, performance and economic analysis of a nanofluid-based photovoltaic/thermal system for residential applications," Energy Conversion and Management, vol. 149, pp. 467484, 2017.

[72] M. R. Salem et al, "Experimental investigation of the performance of a hybrid photovoltaic/thermal solar system using aluminium cooling plate with straight and helical channels," Solar Energy, vol. 157, pp. 147-156, 2017.

\section{BIOGRAPHIES OF AUTHORS}
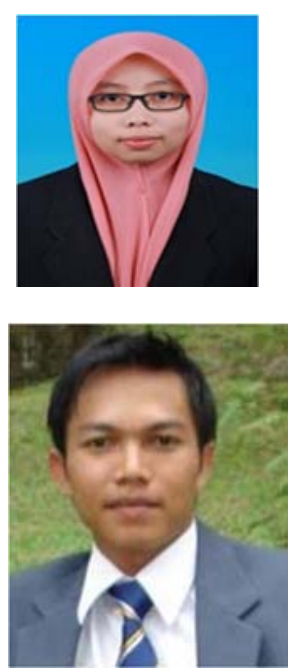

Ahmad Fudholi, Ph.D, M.Sc obtained his S.Si (2002) in physics. He was born in 1980 in Pekanbaru, Indonesia. He served as was the Head of the Physics Department at Rab University Pekanbaru, Riau, Indonesia, for four years (2004-2008). A. Fudholi started his master course in Energy Technology (2005-2007) at Universiti Kebangsaan Malaysia (UKM). After obtaining his Master's, he became a research assistant at UKM until. After his Ph.D (2012) in renewable energy, he became postdoctoral in the Solar Energy Research Institute (SERI) UKM until 2013. He joined the SERI as a lecturer in 2014. He received more than USD 400,000 worth of research grant (16 grant/project) in 2014-2018. He supervised and completed more than 30 M.Sc projects. To date, he has managed to supervise eight Ph.D (six as main supervisors and two as co-supervisor), one Master's student by research mode and one Master's student by coursework mode. He was also an examiner (five Ph.D and one M.Sc). His current research focus is renewable energy, particularly solar energy technology, micropower systems, solar drying systems and advanced solar thermal systems (solar-assisted drying, solar heat pumps, PVT systems). He has published more than 120 peer-reviewed papers, of which 30 papers are in the ISI index (25 Q1, impact factor more than 4) and more than 80 papers are in the Scopus index. He has published more than 80 papers in international conferences. He has a total citations of 1195 and a h-index of 17 in Scopus (Author ID: 57195432490). He has a total citations of 1684 and a h-index of 21 in Google Scholar. He has been appointed as reviewer of high-impact (Q1) journals. He has also been appointed as editor of journals. He has received several international awards. He has also been invited as speaker in the Workshop of Scientific Journal Writing; Writing Scientific Papers Steps Towards Successful Publish in High Impact (Q1) Journals. He owns one patent and two copyrights.

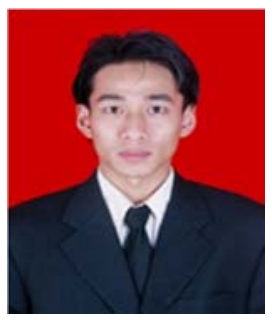

Ivan Taslim, S.Si, M.T from South Sulawesi, Indonesia. He graduated with the M.T in Geology Engineering from University of Hasanuddin in 2014. In 2015, he joined as lecturer at the Department of Geography, Faculty of Science and Technology, University of Muhammadiyah Gorontalo. His main areas of research interest are Management Risk Disaster, Geospatial Data Science and Climate Change with no limited to Renewable Energy. He is currently one of the researchers from USAID SHERA who focuses on developing and using renewable energy in Indonesia. Currently, he is entrusted to work with the Gorontalo Regional Government as a staff in the field of Climate Change and Disaster Mitigation. 

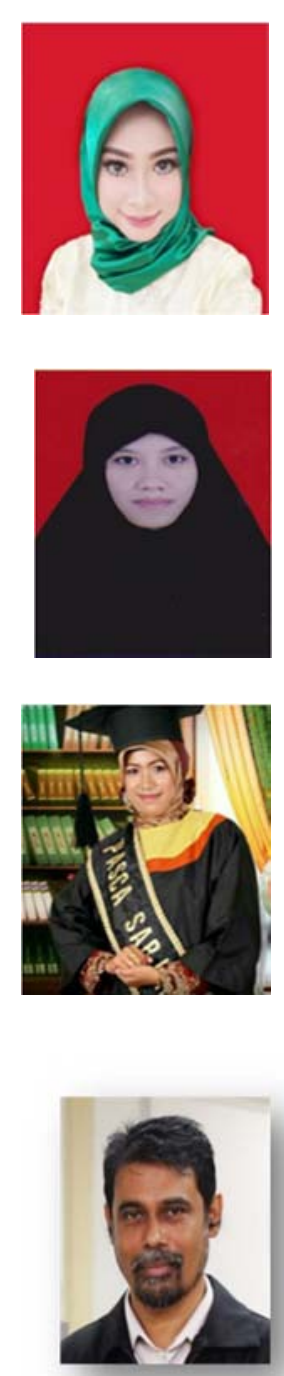

Uce Lestari, S.Farm, M.Farm, Apt obtained his S.Farm (2004) in Pharmacy Technology. She was started his master course in Clinical Pharmacy (2008-2010) at Universitas Andalas. She joined the Faculty of Science and Technology, University of Jambi, Indonesia as a lecturer in 2014. He received more than USD 12,610 worth of research grant (13 grant/project) in 20142018. He supervised and completed of 6 B.Sc projects. His current research focus Clinical and Pharmacy Technology and, particularly utilization of palm kernel shells into a pharmaceutical product technology product that is beneficial to society. She has published more than 23 papers are in the journals and confrences.

Prof Dato' Dr. Kamaruzzaman Sopian graduated with BS Mechanical Engineering at the University of Wisconsin-Madison in 1985, MS in Energy Resources at the University of Pittsburgh in 1989 and PhD in Mechanical Engineering at the Dorgan Solar Laboratory, University of Miami at Coral Gables in 1997. He has been involved in the field of renewable energy for more than 25 years. He has secured research funding of more than USD 6 million from the Malaysian Minstry of Science and the Malaysian Ministry of Education as well as from the industry. He has conducted renewable energy courses in the Asian School of Energy (20072014), which was funded by ISESCO, COMSAT, TIKA and UNESCO. He has published over 700 papers in journals and conferences (SCOPUS $\mathrm{h}$ index $=57$, no. of citations $=11245$; Google Scholar $\mathrm{h}$ index $=69$, no. of citations $=18048)$. He supervised and completed $32 \mathrm{MSc}$ (coursework), $15 \mathrm{MSc}$ (research mode) and $40 \mathrm{PhD}$ students. 